\title{
German philosophy in Vilnius in the years 1803-1832 and the origins of Polish Romanticism
}

\author{
Katarzyna Filutowska ${ }^{1}$
}

Received: 17 May 2019 / Accepted: 12 August 2019 / Published online: 3 September 2019

(c) The Author(s) 2019

\begin{abstract}
This paper focuses on the origins of Polish Romanticism as born partially out of German idealist philosophy. I examine the influence exerted by the ideas of the most significant thinkers, such as Kant, Fichte and Schelling on both professors and students living in Vilnius at the beginning of the nineteenth century (particularly Jan Śniadecki, Józef Gołuchowski and Adam Mickiewicz). As an adherent of Enlightenment and empirical epistemology Śniadecki was critical towards Kant as well as Romantic poetics. On the contrary, in the works of young Gołuchowski, who was well acquainted with German ideas, there are frequent references to Kant, Fichte, and Schelling's philosophy of life. The same ideas - such as vital nature, feeling, and faith as opposed to "dead" knowledge based on "pure terms"- can be found in Mickiewicz's early works. This convergence of motifs is due to the fact that they both have the same source of inspiration: German idealism.
\end{abstract}

Keywords Idealism · Romanticism · Gołuchowski · Mickiewicz · Vilnius University

At the beginning of the nineteenth century, in 1803, the Principal School of the Great Duchy of Lithuania was transformed into the Imperial University of Vilnius. In the paper, I focus on the ways in which German idealist philosophy, represented by Kant, Fichte, or Schelling influenced and inspired its professors and students, famous Polish thinkers and poets—-such as Józef Gołuchowski, Adam Mickiewicz and other members of the Philomath Society-and became one of the most important sources of Polish Romanticism.

What characterized Polish philosophical thought before the Romantic period? The Commission for National Education, founded on the basis of Enlightenment ideas, came into being in Poland in the years 1773-1795. This commission played a significant role in reforming Polish schools and universities according to the principles of Enlightenment ideology. Many well-known Polish scientists and thinkers of

Katarzyna Filutowska

katarzyna.filutowska@gmail.com

1 Institute of Philosophy, University of Warsaw, Warsaw, Poland 
that time - such as Stanisław Staszic, Hugo Kołłątaj and the brothers Jan and Jędrzej Śniadecki-were strongly involved in the activities of this institution. As representatives of the Enlightenment, they were inspired mainly by English empirical philosophy, based on Locke's and Hume's ideas, with its "golden rule" that "Nothing is in the intellect that was not first in the senses" ("Nihil est in intellectu quod non sit prius in sensu"), as well as by Rousseau's thought and the works of the French Encyclopédistes (for instance, Jean le Rond d'Alembert, Denis Diderot, and Charles Montesquieu).

Though this last school is undoubtedly rationalist, it differs from the type of rationalism usually associated with German transcendental philosophy. Empiricism is not indifferent to the origins of transcendental thought. It was Hume's critique of the idea of necessary connections that first inspired Kant's critique of metaphysics. However, there are some fundamental differences between Kant's and Śniadecki's reception of Hume's philosophy. Kant is a rationalist as well. In his short work "Was ist Aufklärung?" ("What is Enlightenment?"), he presents himself as a great adherent of the Enlightenment. Yet, because of his a priori method his thought remains highly speculative in its main principles. Though he accepts the senses as a source of knowledge, he does not reject reason, which according to him, is a sort of higher cognitive faculty endowed with a priori categories, which give form and order to empirical material delivered by the senses. Kant is convinced that because of the character of our cognitive faculties, we perceive reality in time and space. In his Kritik der reinen Vernunft ("Critique of Pure Reason") he enumerates "two pure forms of sensible intuition serving as principles of cognition a priori, namely, space and time" (Kant 1982, 17). The former is a form of an internal intuition and the latter is a form of an external intuition.

Jan Śniadecki's epistemological views are very similar to those of Locke and Hume. He has no doubt that experience is the only source of knowledge and cognition. For him, it is clear that time and space, pure forms of sensible intuition, which, according to Kant, serve as "principles of cognition a priori" (Kant 1982, 17), as well as all other a priori categories of thinking, are innate ideas that undermine the metaphysical phase of philosophy preceding the discoveries of empiricism. He claims that Kant treats "space, that is to say, place (spatium) and time (tempus), as the conditions of being of bodies and calls them forms of sensibility. In this form, which is not gained by senses but is poured from our birth into our soul, everything is transformed into the work of pure reason, all empirical images change into transcendental images" (Śniadecki 1958, 198).

Śniadecki formulated further reproaches against Kant's philosophy bearing on its subject matter as well as its opaque language and form of explanation. Yet the objection mentioned above seems to be the most important one, as it touches upon the central question regarding the clear boundary between the Enlightenment and Romanticism. This key problem has an epistemological character and concerns the way in which we know the world. Śniadecki addressed the issue: "Let us look at the school in Northern Germany-we will see that everything there aims at universal Romanticism. How quickly people have abandoned observation and experience, and the law demonstrated by Locke, that all our cognitions take their beginning from the senses; how quickly they became convinced that a soul has some mysterious power 
of seeing without boundaries, that it has innate knowledge acquired not by the sciences ... but by bringing it into an extraordinary state of being. It was necessary to leave behind all the rules of (common) sense in this new world of investigation." (Śniadecki 1958, 122). Kant's thought belongs to this German school, which aims at universal Romanticism and requires its members to abandon common sense and rational knowledge gained in an empirical way.

However, this is obviously a simplification, as Kant, whose approach is critical, could not be an adherent of typically Romantic epistemology. In inquiring about the conditions of the possibility of knowledge, the boundaries of intellect, and the paralogisms of pure reason, he reaches a turning point in philosophy by indicating the limits of rational cognition. In his rational-empirical epistemology, he considers cognition, sensibility, beauty, the sublime, and so forth. Aesthetics plays a very significant role in Kant's thought. As a sort of science of sensibility it is not reduced to purely poetical aspects but is an integral part of his Critique of Pure Reason. Furthermore, in his Kritik der Urteilskraft ("Critique of Judgement"), Kant distinguishes the trans-facultative faculty of judgement, which brings together theoretical and practical reason (intellect and will). In fact, this third and last of his Critiques deals with teleological and aesthetic issues, in particular, the idea of nature and aesthetic judgement of the sublime and the beautiful.

This paradigm shift in Kant's philosophy makes him one of the most influential forerunners of Romantic poetics. Young people who were seeking new forms of poetical expression-such as Mickiewicz and his friends from the Philomath Society-were under the great influence of romantic ideas. Jan Śniadecki was perfectly aware of this explosive power of new trends in poetry as well as philosophy. As he put it, "Romanticism advises one to leave behind all rules of art. [It] rejects experience, incites imagination against reason, and ignites civil war between the human faculties." (Śniadecki 1958, 124-125).

However, in developing such an uncompromising critique aimed at defending Polish youth against influences of new German thought, Śniadecki was fighting a losing battle. The new, romantic tendencies were too strong and had too many adherents. Furthermore, German ideas were already present in Vilnius at that time. Due to the reform conducted by the Commission for National Education between 1773 and 1794, philosophy, identified with Aristotle's metaphysics, was entirely withdrawn from school programs and replaced by "meagre courses of ethics and logic" (Viliunas 2006, 34). Philosophy came back only in 1803, when the Principal School of the Great Duchy of Lithuania was transformed into the Imperial University of Vilnius.

Johann Heinrich Abicht, who was the university's first professor of philosophy (1804-1816), arrived from Erlangen in Germany as a representative of the new idealist, transcendental thought. Before coming to Vilnius, he published in Germany several books concerning the human will, cognitive faculties, and the philosophy of law and morality. ${ }^{1}$ Their subject matter, as well as the recourse to forms of deduction,

\footnotetext{
1 See for example Neues System einer philosophischen Tugendlehre aus der Natur der Menschheit entwickelt (1790), Philosophie der Erkenntnisse (1791), Neues System eines aus der Menscheit entwikelten Naturrechts (1792), System der Elementarphilosophie oder vollständige Naturlehre der Erkentniß-, Gefühl- und Willenskraft (1795), Psychologische Antropologie (1801) or Verbesserte Logik
} 
show the strong influence of Kant's work, though there are "substantial differences between his thinking and that of the "Kantian school"" (Klemme and Kuehn 2016, 6). Abicht was not a rigorous formalist and appreciated tendencies such as psychologism, sensualism, and eudaimonism in moral philosophy. However, in Lithuania at the beginning of the nineteenth century, he was associated exclusively with Kant and his philosophy (Tunaitis 2006, 27); thus, his influence as a thinker was not substantial.

Nonetheless, he did inspire some of his students, such as Antoni Malawski, who later became a teacher in the Krzemieniec Lycée. In his letters to Joachim Lelewel sent soon after Abicht's death (from May 1816 to March 1817), Malawski admitted that he wrote "a work about philosophy" according to his system and wanted to publish it in Vilnius in Józef Zawadzki's publishing house. He claimed that regarding the problems related to psychology and natural theology, Abicht ordered him to adhere closely to his Encyklopädie der Philosophie. Moreover, he was convinced that this publication would help in propagating a philosophy based on Kant's principles. However, as the author describes in a letter dated March 12th, 1817, the book was not published, as Zawadzki feared he would not be able to sell it.

Anioł Dowgird, who was a philosophy professor at the University of Vilnius on two separate occasions (the first directly after Abicht's death and the second following Gołuchowski's dismissal) knew Kant's works and his philosophy quite well. However, he was not an adherent of transcendental thought. In his own treatises published at that time, he argued with Kant's main principles. He also referred to the views of Fichte, Schelling, Carl Leonhard Reinhold, and Friedrich Bouterweck, but it is obvious that he did not read their original works, and that his critique was based solely on J. M. Degerando's Histoire comparée des systèmes de philosophie (1804). Both Abicht's and Dowgird's cases confirm that, although misreadings and superficial interpretations of German idealism often occurred in Vilnius at that time, nonetheless the school of thought was quite popular and had adherents among young people who read Kant's works and knew of his ideas.

Śniadecki, a rector of Vilna University 1807-1815, a prominent person among Polish educational authorities, was by then an old man. It is assumed that he was aware of how influential the new ideas ultimately proved to be. He did not protest the selection of Józef Gołuchowski as professor of philosophy in 1821, though "a suitable candidate was near at hand in the person of Michał Wiszniewski" (O'Connor 1983, 231), and he knew that Gołuchowski was greatly influenced by "North German" thinkers. In a letter to Czartoryski written in July 1821, he admitted that Gołuchowski's dissertation was based on incorrect principles. However, he was convinced that the young philosopher was a very talented person whose views could be

Footnote 1 (continued)

oder Wahrheitswissenschaft auf den einzig gültigen Begriff der Wahrheit erbaut (1802), Encyklopädie der Philosophie. Mit literarische Notizen (1804). 
easily changed by going to Scotland for a year, reading Thomas Reid's works, and studying the physical sciences. ${ }^{2}$

Though Gołuchowski did, in fact, go abroad, he did not go to Scotland. Instead, he visited Germany, where he met Schelling and became his friend and one of his most zealous students. In Erlangen in 1822 he wrote and published his famous dissertation devoted to Schelling: "Die Philosophie in ihrem Verhältnisse zum Leben ganzer Völker und einzelner Menschen" ("Philosophy in its relation to the life of entire nations and individuals"). This text, as well as two earlier treatises-"Rozprawa konkursowa" ("Tractate") from 1821, and "Ansicht des Einflusses der Mathematik auf die Bildung des Menschen" ("View of the influence of mathematics on human education") from 1816, during his school years in Vienna-confirm Gołuchowski's serious and strong interest in contemporary German philosophy, which shaped his own views and made him one of the forerunners of Polish Romantic thought.

There are several references to the work of Kant and Fichte in Goluchowski's 1816 treatise. For instance, when discussing the problem of advantages of mathematical education, Gołuchowski refers directly to the tenth paragraph of Kant's Critique of Pure Reason, in which Kant underlines the role of imagination, without which we would not be able to be creative, and thus, incapable of any cognition at all (Gołuchowski 1816, 15). ${ }^{3}$ While reason carries out intricate mathematical speculations, imagination enables us to receive inspiration and achieve higher synthesis and unity in our thinking. According to Gołuchowski, "in a harmonious totality of mental faculties none of them should be disregarded ... as there is no an absolute opposition between them" (Gołuchowski 1816, 18). Furthermore, at the end of his dissertation, he refers directly to Fichte's famous treatise "Die Bestimmung des Menschen" ("The Vocation of Man") (1800), written-like Gołuchowski's work devoted to Schelling — "for all educated people", including those who are not professional philosophers (Fichte 1931, XI). ${ }^{4}$ According to Fichte, philosophy proves that "Man is not a product of the world of sense, and the end of his existence cannot be attained in it. His vocation transcends Time and Space, and everything that pertains to sense" as "Our citizenship is in heaven; we have here no continuing city, but we seek one to come" (Fichte 1931, 163-164). In Gołuchowski's conception, mathematics plays quite a similar role. It leads us into the kingdom of eternity where there are no passions, desires, sufferings, and uncertainty characteristic of our empirical

\footnotetext{
2 The letter is quoted by Tadeusz Kozanecki in his short introduction to the full text of Gołuchowski's Tractate from 1821 (Kozanecki 1962, 264-265). As for this problem see also "The document [prepared by the competition committee] emphasized that as a primary condition of his employment Gołuchowski must not follow the theoretical precepts of German writers such as Kant, Fichte, and Schelling which he had introduced in the first part of his dissertation, but be guided by the Christian sensibilities and his own precepts found in the second portion of the treatise" (O'Connor 1983, 234).

3 This treatise was translated to Polish by Maurycy Mochnacki and published in "Dziennik Warszawski" ("Warsaw Daily") in 1825 (Gołuchowski 1825). Gołuchowski refers most probably to the following passage "synthesis generatim is the mere effect of imagination [Einbildungskraft], a blind though indispensable function of the soul, without which we would have no cognition at all" (Kant 1982, 38).

4 See "This book is therefore not intended for the philosopher by profession, who will find nothing in it that has not been already set forth in other writings of the same author. It ought to be intelligible to all readers who are able to understand a book at all" (Fichte 1931, XI).
} 
life, and, as Fichte puts it, "the universe appears ... in a more glorious form. The dead heavy mass ... has vanished; and in its place there flows onward ... an eternal stream of life ... which issues from the original Source of all life-from Thy Life, O Infinite One" (Fichte 1931, 172). According to him, all the mysteries of nature become clear for an individual who looks back and sees "infinite worlds ... sowed in a vast space with the hand of the Almighty" (Gołuchowski 1816, 33), comprehends the harmony of celestial spheres, and feels a "genuine foretaste of heavenly life" (Gołuchowski 1816, 35).

His later treatises contain numerous related ideas, shared with transcendental philosophers_-such as Fichte and Schelling — as well as with the Romantic poets. For Gołuchowski, philosophy is not a purely abstract science, which operates with dead terms but is something similar to Schelling's conception of the living system. This idea is strongly tied to the Romantic view that in order to know the eternal truth we need both faith and the heart. In "Die Bestimmung des Menschen" ("The Vocation of Man") Fichte explains what our human vocation is, and what we should do in order to fulfil it, referring to faith-which is the name of the third and the last chapter of his work. In his middle and late philosophy - that is to say, in the system of the ages of the world-Schelling also claims that faith is the ultimate end of all science. Furthermore, he identifies knowledge with the principle of the whole universe and something which at the same time "knows and initiates the process of creation" (Schelling 1992a, 132). Already in his early transcendental thought he defends the thesis that the ideal principle is the same as the real one (which is identified with the principle of nature) or, as he puts it, that "the object and its concept, the thing and its presentation are originally, absolutely and immediately one" and here is "a principle of all knowledge" (Schelling 1997, 23).

There are many similar ideas in Gołuchowski's Tractate (1821), as well as in his "German" dissertation devoted to Schelling. He is filled with admiration and "holy respect" for "the great and sublime Idea of life" which in his description recalls the process of the objectivation of an absolute self and the problem of the unity of nature and spirit according to Schelling. As he puts it, "Life which is imprisoned in a dead mass of inorganic beings is only a nature's deep contemplation of itself; in plants, it develops as yearning after light and in animals it is set on a higher level and takes a deeper meaning: and how much more in a human being in which nature discovered its innermost thoughts and its greatest aims" (Kozanecki 1962, 297). Furthermore, he is convinced that the sciences reproduce the cosmic system, which provides a foundation for all worlds (Kozanecki 1962, 301); that they supplement and develop life (Kozanecki 1962, 301); that philosophy and life are one and the same; and that "the highest objects can be understood only by the heart" (Kozanecki 1962, 305).

In 1821, Gołuchowski was well acquainted with current German thought. In his competition dissertation there are many ideas related to the works of Kant, Fichte, Schelling, and even Hegel (Vabalaite 2012). Gołuchowski's most famous treatise, devoted to Schelling and written under his personal influence in 1822, when the young philosopher had participated in his lectures and became one of his best friends, provides evidence of an increase in this tendency. According to Wincenty Rymowicz, the similarities to Schelling's philosophy in the 1822 dissertation are deep, significant, and concern practically all the important elements of 
Gołuchowski's own philosophical views-his ontology, epistemology, political philosophy, and philosophy of religion (Rymowicz 1903).

Both Gołuchowski and Schelling claim that all individual empirical beings have their sources in an original unity, the Schellingian Absolute, which knows no difference between the ideal and real, knowledge and being, spirit and nature, subject and object. According to them, a philosopher's role consists in explaining this divine principle, which is the basis of a finite reality and leads us towards God, where everything has its beginning. The philosopher, in Gołuchowski's view, aims to live God's infinite life (Gołuchowski 1822, 35-36) ${ }^{5}$ the philosopher is searching for a type of cognition beyond the merely empirical. According to Gołuchowski, the human mind has divine origins and spiritual depth which contains the fullness of the universe, connects us to the core of all things, and gives us a clear intuition of Eternity in all particular beings (Gołuchowski 1822, 46-47). This view refers to Schelling's idea that nature is a manifestation of an absolute self which in this first, natural phase is not aware of its own creative activity and becomes reflective only in a human, that is, a particular consciousness. In such a process of the objectivation of an absolute principle throughout the world's history, this original depth is gradually spiritualized and finally returns to the ideal, divine principle, to God, who is the Lord of being (Herr des Seyns). He argues that, on a subconscious level, there are still traces of the past of an absolute spirit in its manifestation as nature. In his view, a philosopher seeking to grasp spiritual truth must first delve into the depths of nature, the deepest abyss in which all contradistinctions still coexist in their original states, in an original indifference. This also explains why abstract knowledge based on pure terms is not sufficient, and why Schelling wanted to create a living system.

However, a particular intellect which knows all things in time, space, and causal relations is not able to attain such deep cognition, for it requires intuition (Anschauung), viz., spiritual, internal insight, which allows us to see eternal truths. This is one of the core tenets of idealist epistemology concerning how we perceive, common to Kant, Fichte, and Schelling. Though Kant distinguishes empirical intuition from intelligible intuition, which is, in fact, an idealist paradigm of knowledge that-especially in Fichte and Schelling's thought - is quite similar to Plato's conception of cognition. In his "Philosophische Briefe über Dogmatismus und Kritizismus" ("Philosophical Letters on Dogmatism and Criticism"), Schelling describes it as "a mysterious, wonderful faculty which withdraws us from the changeability of time into our most internal, deprived-of-everything self, which came from the outside, and which allows us to see in ourselves the eternal in the form of the immutable. This intuition is the innermost, the most personal of our experiences which is responsible for all our knowledge about the transcendent world and for everything we believe" (Schelling 1971, 137). In Gołuchowski's treatise we find very similar ideas: "Our mind must be led step by step by intuition until it plunges entirely into this pre-intuition of eternity in which all passion and love flow, all the energy of spiritual activity" (Gołuchowski 1822, 139-140).

\footnotetext{
5 The Polish translation of this treatise by Piotr Chmielowski was published in 1903 (Gołuchowski 1903).
} 
As he states in his inaugural lecture of October 27, 1823, philosophy does not investigate empirical, finite beings which are going to die, but is interested in all those that survived death. Metaphysics, with its philosophical terms, logical proofs and reasoning, will never get to the bottom of such eternal truths, which require the internal sight of the soul. Such cognition is an element of our internal experience and an effect of spiritual insight; hence, in order to be able to acquire it, we must purify our souls of all vices and live in the proper way (Gołuchowski 1842, 246-247). Furthermore, at the highest level of its development, philosophy, the main aim of which is to prepare us to acquire the intuition of the divine and the eternal, becomes one and the same as religion. In his later works, in particular the "Philosophie der Offenbarung" ("Philosophy of Revelation"), Schelling also states that faith is the ultimate end of all knowledge; it is complete knowledge in which there are no more doubts (Schelling 1992b, 413-414).

Finally, Gołuchowski's political views are strongly inspired by Schelling's political conceptions, as well. In particular, he refers to the second deduction of an organic state in Schelling's middle philosophy, presented in the "Stuttgarter Privatvorlesungen" ("Stuttgart private lectures") from 1810. According to Gołuchowski, a state is a living unity, a "wonderful connection" of freedom and necessity, "the most sublime formation shaping itself from the deepest depths of a nation, given and formed directly with it, not attached from the outside" (Gołuchowski 1822, 61). This is an organic formation which manifests the same urge as all other works and forms of nature. Its cells develop successively over the course of history. Gołuchowski claims that every nation should have its own philosophy in order to plunge into the "presource of life" where the nation has its source, and to create a common spirit which is able to unify people, confer spiritual inspiration upon them, and evoke great ideas which are the only source of real and invincible power. ${ }^{6}$

This strongly romantic conception of the state, based on the notion of the nation, affirms values close to those of Herder, such as the spirit of the nation which expresses itself in great ideas, full of genius, which are the only source of the unity and energy necessary to act. According Marc O'Connor, it was one of the most important causes of Gołuchowski's dismissal (O'Connor 1983, 240). ${ }^{7}$ Novosil'cov, who was in Vilnius to investigate the case of the Philomath Society, knew very well that "Gołuchowski had nothing whatever to do with the Philaret/Philomath affair" (O'Connor 1983, 242). However, the statement of August 7, 1824 concerned both the members of the Philomath Society and Goluchowski's lectures, though there was no proof that the latter was involved in the activity of the former. Gołuchowski's

\footnotetext{
${ }^{6}$ Gołuchowski also develops his political philosophy in his later works. For example, in the treatise devoted to the problem of the enfranchisement of peasants, he presents the organic conception of a nation according to which it is the organic body consisting of various parts, similar to such organic beings as "every tree" or "every animal," and so on (Gołuchowski 1851, 620-622).

7 As far as this problem is concerned see also Mark O'Connor's remarks concerning Novosil'cov's reproaches against Gołuchowski's scientific and university activity, which finally led to his dismissal in 1824: "Far more revealing were the scholarly treatises Gołuchowski had written before receiving the position at Vilna. Especially significant was the work Gołuchowski had published two years before at Erlangen" (O’Connor 1983, 240).
} 
political views, presented in the treatise Die Philosophie in ihrem Verhältnisse zum Leben ganzer Völker und einzelner Menschen ("Philosophy in its relation to the life of entire nations and individuals") became a nail in his coffin, for Novosil'cov recognized the affirmation of "an eternal state which was born from the womb of the nation and was educated in the highest national ideas which belonged to the nation for centuries and did not arrive from the outside" (Bieliński 1899-1900, 415) as dangerous for the tsarist government.

Certainly, there were many similar cases and "political" dismissals at many European universities in that period (Beauvois 1977, 109-110). However, it seems that Gołuchowski's romantic views inspired by German idealist philosophy did not make his academic position stronger. According to Maurycy Mochnacki, Gołuchowski's and Lelewel's Vilnius lectures were a turning point, establishing the beginning of the new Romantic age. Inspired by Schelling's philosophy, Gołuchowski "impelled thought to comprehend itself irrespective of an external world", thereby impelling the nation to consider philosophy and to become aware of its own national identity and independence (Mochnacki 1984, 253-254). In 1822, the year of Gołuchowski's "German" treatise, Adam Mickiewicz published his famous volume of poetry "Ballady i romanse" ("Ballads and Romances"), considered to be the first manifesto of Romanticism in Polish literature. In this poetry, he used many romantic motifs, well known from German transcendental philosophy and from Gołuchowski's worksuch as living nature, feeling and faith, as opposed to "dead" knowledge based on abstract terms, intuition or internal insight, etc.

During the same period, Mickiewicz studied at the University of Vilnius. In 1817 he founded the famous Philomath Society with some other students. The Philomaths' letters and documents include remarks which confirm that Mickiewicz and other students in Vilnius at that time had a general idea about Kant and Schelling's philosophy, even if they were not well-versed in its details. Stefan Harassek underlines that the Philomaths_-in particular, Józef Jeżowski and Franciszek Malewski"had watched the development of German thought attentively" (Harassek 1916, 171; see also Ciechanowska 1925, 95).

Mickiewicz had likely studied Kant's aesthetic views, as in a letter to Józef Jeżowski of September 30, 1820 he wrote that he needed "explanations of Kant" in order to better understand "aestheticians from his school" (Czubek 1913, 309). He knew well the main principles of the aesthetics of the sublime that he applied already in his early poems, for example "Romantyczność" ("Romanticism") or "Świtezianka" ("The Nixie"). In an article from 1898 concerning Mickiewicz's philosophical views, Piotr Chmielowski refers to the two, as he puts it, "oldest" letters written in Kovno in the summer of 1821, in which the poet mentioned that he had read some works by Kant and Schelling (Chmielowski 1897-1898, 7-8; Zarych 2010, 110-113). Unfortunately, Chmielowski does not list their titles, but it is quite obvious Mickiewicz had studied Schelling's philosophy, as he writes facetiously that "his treatise concerning the absolute does not compare to mine" (Chmielowski 1897-1898, 8) and then quotes his poem "Do*, w sztambuchu" ("To*, in the album") in which Schelling's idea of original indifference (Indifferenz) and primordial identity of opposed terms, such as subject and object, spirit and nature, the ideal and the real in the absolute is replaced by the poetic vision of two persons 
who live in two different worlds and must love each other with hatred (Chmielowski 1897-1898, 8).

Certainly, such a facetious interpretation of Schelling's philosophy of identity is very superficial. However, it proves that Mickiewicz was influenced by German transcendental thought, which, besides German and British poetry and literature of that period, was one of the most important sources of his poetic inspiration. In Mickiewicz's later work, there are further traces which confirm such a thesis. For instance, some of the motifs, words, and expressions used in his famous poem "Romantyczność" ("Romanticism") are very similar to those used by Schelling and Gołuchowski.

These are not only elements of poetic imagination but sometimes very clearly and literally reflect Mickiewicz's epistemological views, as seen, for instance, in the final postulate addressed to the reader "You don't know living truths, won't see wonders! / Have a heart and look into the heart" (Mickiewicz 1998, 39). Such expressions as "feeling and faith" or living knowledge which speaks stronger than dead truths proclaimed by the "man of learning", or even the quote from Shakespeare's "Hamlet" ("Methinks I see... Where? In my mind's eyes.") are a clear manifestation of the author's romantic epistemological convictions. These are also great romantic polemics with the Enlightenment and empiricism, represented by Jan Śniadecki, portrayed in Mickiewicz's poem as a "man of learning" with "a lens and an eye".

To sum up, the problems presented here are not the only examples of the influence of German idealist thought on Polish thinkers and poets living in Vilnius at that time, though they are crucial for understanding the beginnings of Polish Romanticism. The opinion, according to which these two bodies of work-Gołuchowski's philosophy and Mickiewicz's early poetry-should be considered together as a manifestation of one tendency which began in Vilnius in 1822, is quite popular among Polish philosophers. As mentioned above, Maurycy Mochnacki shared this idea and expressed it explicitly in his well-known work "Powstanie narodu polskiego w roku 1830 i 1831" ("The uprising of the Polish Nation in the year 1830 and 1831"). It is necessary to emphasize that he was not the only one convinced that 1822 was a genuine turning point for Polish thought as well as literature and public life. Another well-known Polish philosopher, Maurycy Straszewski, professor of the Jagiellonian University in Cracow, wrote in his "Historia filozofii w Polsce" ("The History of Philosophy in Poland," published posthumously in 1930) that "Gołuchowski's philosophy is essentially, beside Mickiewicz's first poems, an announcement of a magnificent flight of Polish creation in the direction of Romanticism and idealism-[the flight] which began in Vilnius in the third decade of the last century" (Straszewski 1930, 39).

Such a coincidence of motifs does not seem to be entirely accidental, but resulted from the fact that Gołuchowski, like other Polish Romantics, was greatly influenced by Schelling and other German authors, such as Kant, Schiller, Goethe, and Herder. Schelling heavily influenced the romantic conception of living nature (Janion 1975, 252, 261-263) and was one of the most important sources of inspiration for Polish thinkers and poets of the first half of the nineteenth century, especially Maurycy Mochnacki and Adam Mickiewicz (Janion 2001, 115-116; Zarych 2010, 99-127). Furthermore, Schiller "became for a long time the Philomath's favorite author" (Witkowska 1998, 273). 
Gołuchowski was a professional philosopher, well-acquainted with the most important transcendental works, and perfectly understood German idealist thought. Furthermore, he participated in Schelling's lectures and knew him personally. ${ }^{8}$ Mickiewicz was a poet, not a philosopher. He had a rather passing acquaintance with Schelling and Kant's works, limited to those that were most popular for Romantic terms or ideas, such as living nature, the absolute or faith and intuition. However, the sources of inspiration are the same in both cases. Affirming Anti-Enlightenment epistemology, idealist philosophy, and Schelling's organic conception of the unity of spirit and nature, both became forerunners of a new, Romantic age.

Acknowledgements The article written in the framework of the "Ideentransfer - Mobilität - Wandel: Deutsche Kultur und Wissenschaft in Wilna (1803-1832)" research project funded by the Federal Government Commissioner for Culture and the Media upon a Decision of the German Bundestag (Grant holder: dr hab. Monika Bednarczuk, Project Number $\mathrm{K}_{44}$ 43000/ 11\#21). Furthermore, I would like to thank professor Tomasz Kupś from the Nicolaus Copernicus University in Torun for providing me access to the unpublished letters of Antoni Malawski to Joachim Lelewel. They will be included in the volume "Kantiana wileńskie" which will soon be published.

Funding This study was funded by the Federal Government Commissioner for Culture and the Media upon a Decision of the German Bundestag (Grant Number $\mathrm{K}_{44} 43000 / 11 \# 21$ ).

\section{Compliance with ethical standards}

Conflict of interest The author declares that there is no conflict of interest.

Open Access This article is distributed under the terms of the Creative Commons Attribution 4.0 International License (http://creativecommons.org/licenses/by/4.0/), which permits unrestricted use, distribution, and reproduction in any medium, provided you give appropriate credit to the original author(s) and the source, provide a link to the Creative Commons license, and indicate if changes were made.

\section{References}

Beauvois, D. (1977). Lumières et société en Europe de l'Est. L'Université de Vilna et les écoles polonaises de l'Empire russe (1803-1832). Tome I. Lille: Universite de Lille III. Paris: Librairie H. Champion.

Bieliński, J. (1899-1900). Uniwersytet Wileński (1579-1831). Volume II. Kraków: Akademia Umiejętności.

Chmielowski, P. (1897-1898). Poglądy filozoficzne Mickiewicza. Przeglad Filozoficzny, 4, 1-43.

Ciechanowska, Z. (1924-1925). Mickiewicz a Goethe (Ze studiów nad znajomością Goethego w Polsce). Pamiętnik Literacki, 21(1/4), 92-125.

Czubek, J. (Ed.). (1913). Korespondencja filomatów. (Vol. II). Kraków: Akademia Umiejętności.

Fichte, J. G. (1931). The vocation of man. Chicago: The Open Court Publishing Company.

\footnotetext{
${ }^{8} \mathrm{He}$ writes about this in his posthumously published two-volume work "Dumania nad najwyższemi zagadnieniami człowieka" ("Thoughts about the highest human issues," 1861) in which he widely discusses, among other things, the main principles of, as Jan Śniadecki defined it, "North German" conceptions (Gołuchowski 1861, 218-220). We find a confirmation of this friendship, which began in 1821 and lasted until Schelling's death in 1854, in the German philosopher's Tagebücher (Schelling 1998, 5, 21, 23).
} 
Gołuchowski, J. (1816). Ansicht des Einflusses der Mathematik auf die Bildung des Menschen, welche bei der Gelegenheit einer besonderen und strengeren Prüfung aus dieser Wissenschaft Joseph Gołuchowski, Zögling der k. k. Theresianischen Ritter-Akademie geäussert hat. Wien: Georg Überreuter.

Gołuchowski, J. (1822). Die Philosophie in ihrem Verhältnisse zum Leben ganze Völker und einzelner Menschen. Erlangen: Bei J. J. Palm und E. Enke.

Gołuchowski, J. (1825). O wpływie matematyki na wykształcenie człowieka. Dziennik Warszawski, 2, 3-36.

Gołuchowski, J. (1842). Otwarcie kursu filozofii w Wilnie 1823/1824. Biblioteka Warszawska, 2, $225-258$.

Gołuchowski, J. (1851). Rozbiór kwestyi włościańskiej w Polsce i w Rossyi w r. 1850. Poznań: Księgarnia J. K. Żupańskiego.

Gołuchowski, J. (1861). Dumania nad najwyższemi zagadnieniami człowieka poprzedzone historycznem rozwinięciem głównych systematów filozoficznych od Kanta do najnowszych czasów (Vol. 2). Wilno: J. Zawadzki.

Gołuchowski, J. (1903). Filozofia i życie. Warsaw: Księgarnia E. Wendego i Sp.

Harassek, S. (1916). Kant w Polsce przed rokiem 1830. Warsaw: Gebethner i Wolff.

Janion, M. (1975). Goraczka romantyczna. Warsaw: Państwowy Instytut Wydawniczy.

Janion, M. (2001). Prace wybrane. Romantyzm i jego media (Vol. 4). Kraków: Universitas.

Kant, I. (1982). Critique of pure reason. Translated by Wolfgang Schwarz. Aalen: Scientia

Klemme, H. F., \& Kuehn, M. (Eds.). (2016). The Bloomsbury dictionary of eighteenth-century German philosophers. London: Bloomsbury Publishing.

Kozanecki, T. (1962). Rozprawa konkursowa (1821) J. Gołuchowskiego. Archiwum Historii Filozofii $i$ Myśli Spotecznej, 8, 261-311.

Mickiewicz, A. (1998). The sun of liberty. Bicentenary anthology 1798-1998. Warsaw: Energeia.

Mochnacki, M. (1984). Powstanie narodu polskiego w roku 1830 i 1831 (Vol. I). Warsaw: Państwowy Instytut Wydawniczy.

O'Connor, M. (1983). Czartoryski and the Gołuchowski Affair at Vilna University. Jahrbucher fur Geschichte Osteuropas. Neue Folge, 31(2), 229-243.

Rymowicz, W. (1903). Die Philosophie von Joseph Gołuchowski und Ihre Abhängigkeit von Schellings Weltanschauung. Freiburg: St.-Paulus Druck.

Schelling, F. W. J. (1971). Frühschriften. Eine Auswahl in zwei Bänden. Erster Band. Berlin: Akademie Verlag.

Schelling, F. W. J. (1992a). Urfassung der Philosophie der Offenbarung. Teilband 1. Hamburg: Felix Meiner Verlag.

Schelling, F. W. J. (1992b). Urfassung der Philosophie der Offenbarung. Teilband 2. Hamburg: Felix Meiner Verlag.

Schelling, F. W. J. (1997). System of transcendental idealism. Charlottesville: University Press of Virginia.

Schelling, F. W. J. (1998). Philosophische Entwürfe und Tagebücher. 1846. Philosophie der Mythologie und reinrationale Philosophie. Hamburg: Felix Meiner Verlag.

Śniadecki, J. (1958). Pisma filozoficzne (Vol. II). Warsaw: PWN.

Straszewski, M. (1930). Historia filozofii w Polsce. Kraków: Wydawnictwo Księży Jezuitów.

Tunaitis, S. (2006). Zarysy filozofii kantowskiej u J. H. Abichta. Colloquia Communia, 1-2, 27-33.

Vabalaite, R. M. (2012). The Reception of German Philosophy in the Tractate of Józef Gołuchowski. Societal Studies, 4(1), 7-18.

Viliunas, D. (2006). Typy filozofa salonowego w epoce Oświecenia na Litwie. Colloquia Communia, $1-2,34-40$.

Witkowska, A. (1998). Rówieśnicy Mickiewicza. Życiorys jednego pokolenia. Warsaw: Oficyna Wydawnicza Rytm.

Zarych, E. (2010). Romantycy, myśliciele, inspiratorzy. Badania nad wptywem filozofii niemieckiej - od Kanta do Hegla - na literature polskiego romantyzmu. Gdańsk: słowo/ obraz terytoria.

Publisher's Note Springer Nature remains neutral with regard to jurisdictional claims in published maps and institutional affiliations. 